\title{
STUDY OF RED CELL ENZYME SYSTEMS IN TEHRAN AND ISFAHAN IRANIANS
}

\author{
Kanwarjit S. SAwhney, ${ }^{1,3}$ Eric Sunderland, ${ }^{2}$ and Dariush D. FARHud ${ }^{3, *}$ \\ ${ }^{1}$ Helale Ahmar Blood Tranfusion Service, Tehran, Iran \\ ${ }^{2}$ Department of Anthropology, University of Durham, U.K. \\ ${ }^{3}$ Unit of Human Genetics and Anthropology, School of Public Health, \\ University of Tehran, P.O. Box 1310, Tehran, Iran
}

\begin{abstract}
Summary Blood samples from Tehran and Isfahan were examined for seven red cell enzyme systems. Polymorphic variations was present for acid phosphatase, phosphoglucomutase locus I, adenylate kinase, 6-phosphogluconate dehydrogenase and phosphohexose isomerase loci controlling red cell enzyme systems. Statistical analysis demonstrated no significant variation between the two Iranian samples. Gene frequencies were compared with the distribution pattern known in other Iranian populations. The lactate dehydrogenase and Malate dehydrogenase systems were monomorphic.
\end{abstract}

\section{INTRODUCTION}

Few published observations are available on the red cell enzymes of the inhabitants of Iran. Bowman and Ronaghy (1967) first studied the distribution of some enzymes in the Moslems of Iran. Subsequently others looked at some other populations in Iran (Undevia et al., 1972; Farhud et al., 1973; Lehman et al., 1973; Miyashita et al., 1975; Kirk et al., 1977). Still our knowledge about the distribution of polymorphic systems in Iran is limited. Thus the present survey has been conducted to enlarge our knowledge of the red cell enzyme groups in Iran.

\section{MATERIALS AND METHODS}

Blood samples were obtained from two cities of Iran, i.e. Tehran in the North and Isfahan in the Centre. All the individuals belonged to the cities and were healthy and unrelated. Blood samples from Tehran, mainly obtained from blood donors, were provided by the Helale Ahmar Blood Transfusion Service. From Isfahan, the samples were collected by authorities of the Clinical Biochemistry Department, Univ. of Isfahan. Haemolysates were prepared by the carbon tetrachloride method of

Received August 3, 1981

* Offprint requests to D.D. Farhud. 
Ager and Lehman (1961). Phosphoglucomutase (PGM), acid phosphatase (AP) and adenylate kinase (AK) were typed by the methods of Spencer et al. (1963), Hopkinson et al. (1963) and Fildes and Harris (1966), respectively. For dehydrogenase enzymes, one half of the gel was stained for 6-PGD and G-6PD by the method of Fildes and Parr (1963) and the other half was stained for lactate dehydrogenase (LDH) and malate dehydrogenase (MDH) as described by Kirk et al. (1971). Phosphohexose isomerase (PHI) was performed by the method of Detter et al. (1968).

\section{RESULTS AND DISCUSSION}

The results on the red cell enzyme variants are given in Tables 1 and 2 . Gene frequencies were calculated by the gene counting method. Appropriate $\chi^{2}$ analysis, assuming Hardy Weinberg equilibrium, revealed no significant departure from expectation for any of the system. No major difference was found between the two samples.

\section{a. Acid phosphatase (AP)}

Table 3 shows that $P^{b}$ is the most common of the three major alleles in each Iranian sample investigated. Its frequency ranges from 0.6429 in the Kurds of Marivan and Baneh (Lehman et al., 1973) to 0.7500 in the Zoroastrian Iranis of Bombay (Undevia et al., 1972). A lower range of values $(0.2292$ to 0.4043$)$ characterizes the $P^{a}$ allele. The present values of $P^{a}(0.3193)$ and $P^{b}(0.6618)$ are within the range of variation. The $P^{c}$ gene is present in all the Iranian populations tested so far, the highest frequency being 0.030 .

\section{b. Phosphoglucomutase locus I ( $\left.P G M_{1}\right)$}

In general, the $P G M_{1}$ frequencies of the Iranians show marked similarities to Middle East and European values. The frequencies of $P G M_{1}^{2}$ in the Iranian populations lie between the limits of 0.2208 and 0.3480 . The frequencies of $P G M_{1}$ alleles are consistent with the distribution pattern known in other Iranian populations (see Table 3). Besides the common three phenotypes, some variant type PGM 6-1, was present in the Isfahan Iranians. Similar type of variant was found in the Caspian littoral area (Kirk et al., 1977).

\section{c. Adenylate Kinase ( $A K$ )}

As can be seen from the Table 3, very few observations for the AK system on Iranians have been reported so far. Bowman and Ronaghy (1967) found a frequency of 0.0497 for $A K^{2}$ allele in Iranian Moslems and Undevia et al. (1972) give a value of 0.0670 among the Parsis living in Bombay. These values are similar to those found in the present investigation for the Iranians (0.0498). In European populations, the frequencies of the $A K^{2}$ gene lie between the limits of 0.015 and 0.056 (Bhasin and Fuhrmann, 1972). Reported values in the Middle East range from 
Table 1. The distribution of red cell enzyme groups in Tehran and Isfahan Iranians.

\begin{tabular}{|c|c|c|c|c|c|c|c|}
\hline \multirow{2}{*}{\multicolumn{2}{|c|}{ System }} & \multicolumn{2}{|c|}{ Tehran Iranians } & \multicolumn{2}{|c|}{ Isfahan Iranians } & \multicolumn{2}{|c|}{ Total } \\
\hline & & No. & $\%$ & No. & $\%$ & No. & $\%$ \\
\hline \multicolumn{8}{|c|}{ Acid phosphatase } \\
\hline \multirow[t]{4}{*}{$\mathrm{AP}$} & A & 21 & 13.04 & 6 & 7.79 & 27 & 11.34 \\
\hline & $\mathrm{AB}$ & 68 & 42.24 & 30 & 38.96 & 98 & 41. 18 \\
\hline & $\mathrm{B}$ & 65 & 40.37 & 39 & 50.65 & 104 & 43.70 \\
\hline & $\mathrm{BC}$ & 7 & 4.35 & 2 & 2.60 & 9 & 3.78 \\
\hline Total & & 161 & 100.00 & 77 & 100.00 & 238 & 100.00 \\
\hline \multicolumn{8}{|c|}{ Phosphoglucomutase locus I } \\
\hline \multirow[t]{4}{*}{ PGM } & $1-1$ & 101 & 61.21 & 50 & 58.14 & 151 & 60.16 \\
\hline & $2-1$ & 50 & 30.30 & 28 & 32.56 & 78 & 31.07 \\
\hline & $2-2$ & 14 & 8.48 & 7 & 8.14 & 31 & 8.37 \\
\hline & $6-1$ & - & - & 1 & 1.16 & 1 & 0.40 \\
\hline Total & & 165 & 99.99 & 86 & 100.00 & 251 & 100.00 \\
\hline \multicolumn{8}{|c|}{ Adenylate kinase } \\
\hline \multirow[t]{3}{*}{$\mathrm{AK}$} & $1-1$ & 150 & 89.29 & 76 & 91.57 & 226 & 90.29 \\
\hline & $2-1$ & 18 & 10.71 & 7 & 8.43 & 25 & 9.46 \\
\hline & $2-2$ & - & - & - & 一 & - & 0.25 \\
\hline Total & & 168 & 100.00 & 83 & 100.00 & 251 & 100.00 \\
\hline \multicolumn{8}{|c|}{ 6-Phosphogluconate dehydrogenase } \\
\hline \multirow[t]{3}{*}{ 6-PGD } & A & 157 & 95.15 & 84 & 94.38 & 241 & 94.88 \\
\hline & $\mathrm{Ca}$ & 8 & 4. 85 & 5 & 5.62 & 13 & 5.12 \\
\hline & $\mathrm{C}$ & - & - & - & - & - & - \\
\hline Total & & 165 & 100.00 & 89 & 100.00 & 254 & 100.00 \\
\hline \multicolumn{8}{|c|}{ Phosphohexose isomerase } \\
\hline \multirow[t]{3}{*}{ PHI } & $1-1$ & 163 & 98.79 & $89 \mathrm{a}$ & 100.00 & & - \\
\hline & $3-1$ & 2 & 1.21 & - & - & & - \\
\hline & $3-3$ & - & - & - & & & - \\
\hline Total & & 165 & 100.00 & 89 & 100.00 & & - \\
\hline \multicolumn{8}{|c|}{ Lactate dehydrogenaseb } \\
\hline LDH & & 165 & & 89 & & & \\
\hline \multicolumn{8}{|c|}{ Malate dehydrogenase } \\
\hline MDH & & 165 & & 89 & & & \\
\hline
\end{tabular}

a All 89 Isfahan Iranians tested for PHI showed the type 1-1. b All LDH samples were normal.

- All MDH samples exhibited type 1-1. 
Table 2. Gene frequencies for red cell enzyme groups in Tehran and Isfahan Iranians.

\begin{tabular}{|c|c|c|c|c|}
\hline \multicolumn{2}{|c|}{ System } & Tehran Iranians & Isfahan Iranians & Total \\
\hline \multicolumn{5}{|c|}{ Acid phosphatase } \\
\hline \multirow[t]{3}{*}{ AP } & $p^{a}$ & 0.3416 & 0.2727 & 0.3193 \\
\hline & $p^{b}$ & 0.6367 & 0.7143 & 0.6618 \\
\hline & $p^{c}$ & 0.0217 & 0.0130 & 0.0189 \\
\hline \multicolumn{5}{|c|}{ Phosphoglucomutase } \\
\hline \multirow[t]{3}{*}{ PGM } & $P G M_{1}^{1}$ & 0.7636 & 0.7500 & 0.7590 \\
\hline & $P G M 1^{2}$ & 0.2364 & 0.2442 & 0.2390 \\
\hline & $P G M_{1}{ }^{6}$ & - & 0.0058 & 0.0020 \\
\hline \multicolumn{5}{|c|}{ Adenylate kinase } \\
\hline \multirow[t]{2}{*}{ AK } & $A K^{1}$ & 0.9464 & 0.9578 & 0.9502 \\
\hline & $A K^{2}$ & 0.0536 & 0.0422 & 0.0498 \\
\hline \multicolumn{5}{|c|}{ 6-Phosphogluconate dehydrogenase } \\
\hline \multirow[t]{2}{*}{ 6-PGD } & $P G D A$ & 0.9758 & 0.9719 & 0.9744 \\
\hline & $P G D^{c}$ & 0.0242 & 0.0281 & 0.0256 \\
\hline \multicolumn{5}{|c|}{ Phosphohexose isomerase } \\
\hline \multirow[t]{2}{*}{ PHI } & $P H{ }^{1}$ & 0.9939 & - & - \\
\hline & $P H I^{3}$ & 0.0061 & - & - \\
\hline
\end{tabular}

0.0252 to 0.0687 (Tills et al., 1971a). The present value of 0.0498 falls within this range and demonstrates a similarity between different populations of the Middle East and Europe.

\section{d. 6-Phosphogluconate dehydrogenase (6-PGD)}

As for the AK system, observations for 6-PGD in Iranians are very limited. Farhud et al. (1973) gave a value of 0.0153 for the $P G D^{C}$ allele in Iranians and Bowman and Ronaghy (1967) found a value of 0.0280 in Iranian Moslems. The $P G D^{C}$ frequency of 0.0256 in this survey is comparable with the earlier samples. Further comparison with the Kurdish series of Lehman et al. (1973) shows that the Kurds of Marivan and Baneh have the highest frequency of $P G D^{C}(0.0714)$ in Iran. The value of $P G D C$ shown for the Iranians in Tables 3 are within the range for Europeans. However, it is lower than for some Middle Eastern populations (Tills et al., 1971b).

\section{e. Phosphohexose isomerase (PHI)}

Variants of PHI have been reported to be absent in Iranians (Farhud et al., 1973). In this survey, however, two Iranians from Tehran exhibited the 3-1 phenotype. Detter et al. (1968) found that the Asiatic populations exhibit an appreciable frequency of the allele $\mathrm{PHI}_{1}^{3}$ and the present survey confirms this tendency. 


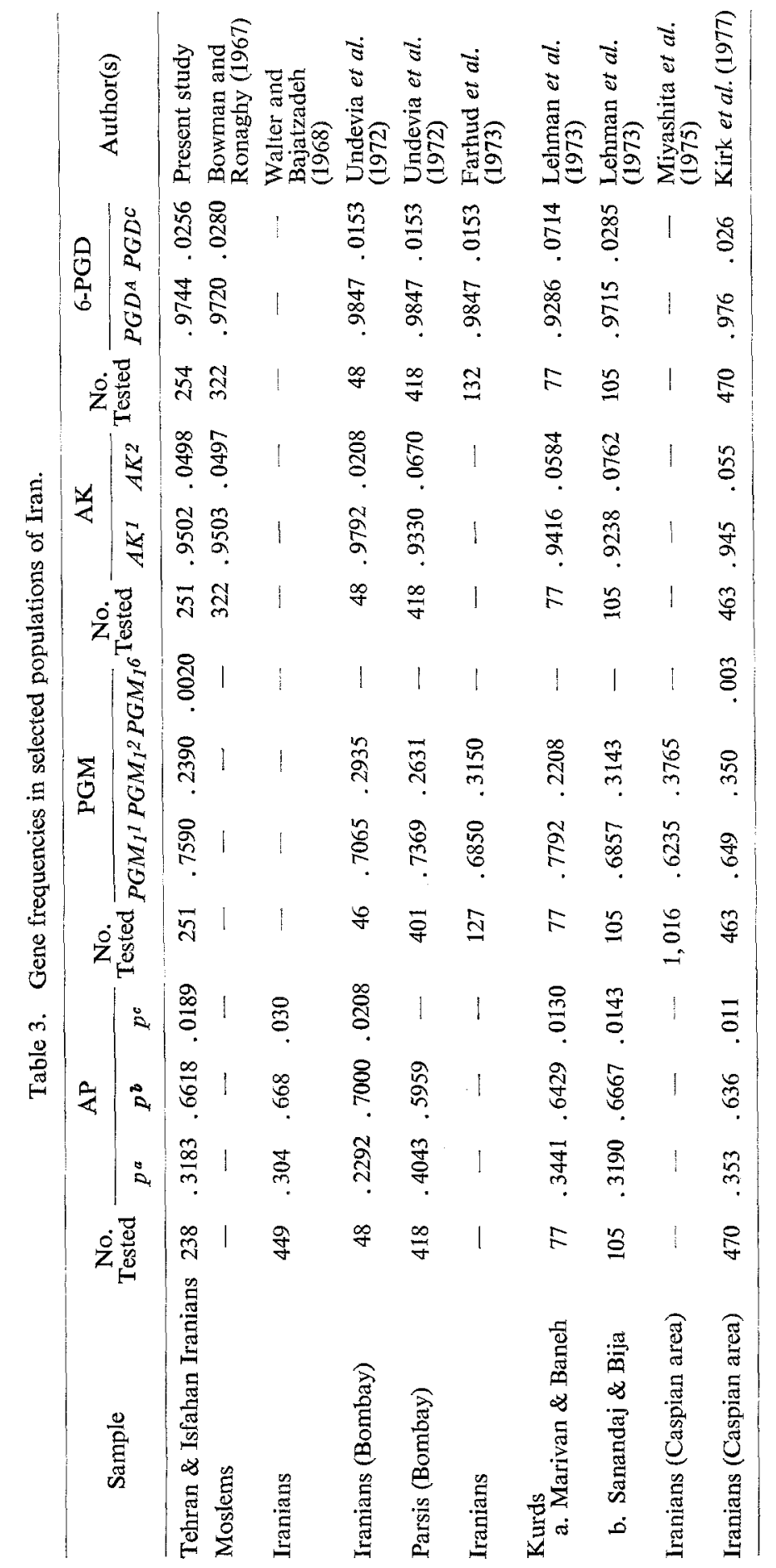




\section{f. Lactate dehydrogenase ( $L D H)$}

Genetic variants of LDH are rare, only one case of LDH Cal-1 has been reported in the Iranians of Caspian area (Kirk et al., 1977). In the present series a total of 254 samples examined yielded only normal pattern.

g. Malate dehydrogenase ( $M D H)$

A single case of s-MDH 5-1 have been found in the Caspian (Kirk et al., 1977). However, all of the samples in the present series showed the normal type.

\section{REFERENCES}

Ager, J.A.M., and Lehman, H. 1961. Laboratory detection of abnormal haemoglobins. Ass. Clin. Path. Broadsheet. 33.

Bhasin, M.K., and Fuhrmann, W. 1972. Geographic and ethnic distribution of some red cell enzymes. Humangenetik 14: 204-223.

Bowman, J., and E. Ronaghy, H. 1967. Haemoglobin, glucose-6-phosphate dehydrogenase and adenylate kinase polymorphism in Moslems in Iron. Am. J. Phys. Anthrop. 27: 119-123.

Detter, J.C., Ways, P.O., Giblett, E.R., Baugham, M.A., Hopkinson, D.A., Poey, S., and Harris, H. 1968. Inherited variations in human phosphohexose isomerase. Ann. Hum. Genet. 31: 329338.

Farhud, D.D., Ananthakrishnan, R., Walter, H., and Loser, J. 1973. Electrophoretic investigations of some red cell enzymes in Iran. Hum. Hered. 23: 263-266.

Fildes, R., and Parr, C.W. 1963. Human red cell phosphogluconate dehydrogenase. Nature 200: $890-891$.

Fildes, R.A., and Harris, H. 1966. Genetically determined variation of adenylate kinase in man. Nature 209: 261-263.

Hopkinson, D.A., Spencer, N., and Harris, H. 1963. Red cell acid phosphatase variants; a new human polymorphism. Nature 199: 969-971.

Kirk, R.L., Blake, N.M., Moodie, P.M., and Tibbs, G.J. 1971. Population genetic studies in Australian aborigines of the Northern Territory. Hum. Biol. Oceania. 1: 54-76.

Kirk, R.L., Keats, Bronya, Blake, N.M., McDermid, E.M., Ala, F., Karimi, M., Nickbin, B., Shabazi, H., and Kmet, J. 1977. Genes and people in the Caspian littoral: A population genetic study in Northern Iran. Am. J. Phys. Anthrop. 46: 377-390.

Lehman, H., Ala, F., Hedeyat, S., Montazemi, K., Nejad, H.K., Lightman, S., Kopec, A.C., Mourant, A.E., Teasdale, P., and Tills, D. 1973. The hereditary blood factors of the Kurds of Iran. Phil. Trans. R. Soc. Lond. 266: 195-205.

Miyashita, T., Ohkura, K., Matsumoto, H., and Matsumoto, K. 1975. Distribution of polymorphic traits in Iran. Jpn. J. Hum. Genet. 20:55.

Tills, D., Vanden Braden, J.L., Clements, V.R., and Mourant, A.E. 1971a. The world distribution of electrophoretic variants of red cell adenylate kinase. Hum, Hered. 21: 302-304.

Tills, D., Vanden Braden, J.L., Clements, V.R., and Mourant, A.E. 1971b. The distribution in man of genetic variants of 6-phosphogluconate dehydrogenase. Hum. Hered. 21: 305-308.

Undevia, J.V., Blake, N.M., Kirk, R.L., and McDermid, E.M. 1972. The distribution of some enzyme group systems among Parsis and Iranis in Bombay. Hum. Hered. 22: 274-282.

Walter, H., and Bajatzadeh, M, 1968. Studies on the distribution of the human red cell acid phosphatase in Iranians and other populations. Acta Genet. 18: 421-428. 